BNL 50799

\title{
158
}

$-78$

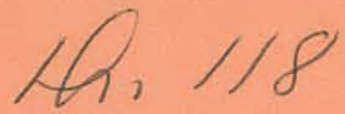

\section{ANNUAL HIGHLIGHTS OF THE ENERGY TECHNOLOGY PROGRAMS}

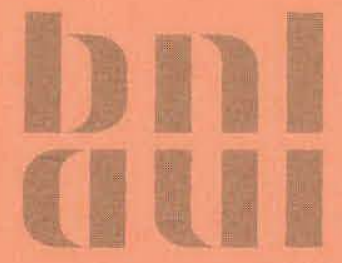

December 1977

DEPARTMENT OF ENERGY AND ENVIRONMENT

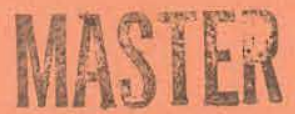

BROOKHAVEN NATIONAL LABORATORY ASSOCIATED UNIVERSITIES, INC. UNDER CONTRACT NO. EY-76-C-02-0016 WITH THE

UNITED STATES DEPARTMENT OF ENERGY 


\section{DISCLAIMER}

This report was prepared as an account of work sponsored by an agency of the United States Government. Neither the United States Government nor any agency Thereof, nor any of their employees, makes any warranty, express or implied, or assumes any legal liability or responsibility for the accuracy, completeness, or usefulness of any information, apparatus, product, or process disclosed, or represents that its use would not infringe privately owned rights. Reference herein to any specific commercial product, process, or service by trade name, trademark, manufacturer, or otherwise does not necessarily constitute or imply its endorsement, recommendation, or favoring by the United States Government or any agency thereof. The views and opinions of authors expressed herein do not necessarily state or reflect those of the United States Government or any agency thereof. 


\section{DISCLAIMER}

Portions of this document may be illegible in electronic image products. Images are produced from the best available original document. 
BNL 50799

UC-13

(General, Miscellaneous, and

Progress Reports (NONNUCLEAR)

TID-4500)

\section{ANNUAL HIGHLIGHTS OF THE ENERGY TECHNOLOGY PROGRAMS}

\section{December 1977}

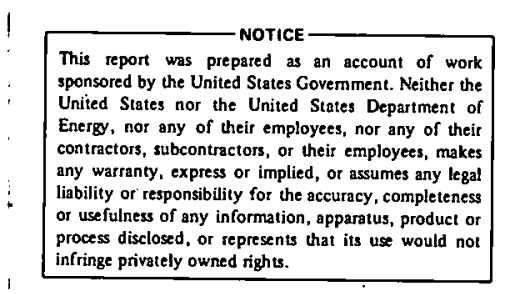

DEPARTMENT OF ENERGY AND ENVIRONMENT

BROOKHAVEN NATIONAL LABORATORY

UPTON, NEW YORK 11973 



\section{PREFACE}

The energy technology program in the Department of Energy and Environment includes the following major areas and program activities within those areas.

\section{CONSERVATION AND SOLAR APPLICATIONS}

- oil and gas fired space conditioning systems

- energy conservation in buildings

- solar assisted heat pumps and cooling systems

- technology transfer

- conservation program management

\section{ENERGY TECHNOLOGIES}

- energy storage by chemical means

- energy conversion in fuel cells and combustion devices

- fossil energy conversion, combustion, and environmental control

- program management

Related fossil energy programs are conducted in the Process Sciences Division and are described in the Energy Sciences program highlights.

A separate conservation program management group (CPMG) is responsibie for the management of programs in electrolysis based hydrogen storage systems, hydrogen-halogen energy storage systems; space conditioning, diagnostics, and controls; and residential buildings conservation.

The individual projects are summarized and the significant accomplishments in 1977 are presented.

Robert J. Isler 
Preface $\ldots \ldots \ldots \ldots \ldots \ldots \ldots \ldots \ldots \ldots \ldots \ldots \ldots \ldots \ldots \ldots \ldots \ldots \ldots \ldots \ldots$

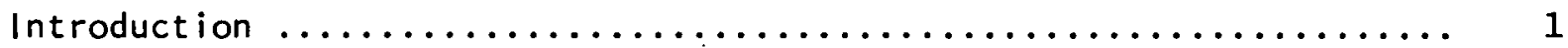

Energy Storage and Conversion Division

Electrolysis Based Hydrogen Energy Storage Systems ........... 6

An Electrochemically Regenerative Hydrogen-Halogen Energy

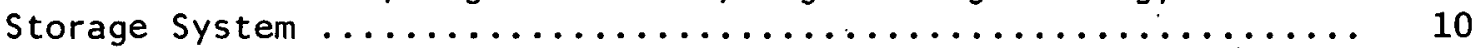

Fuel Cells: Applied Research Fuel Cell Materials and

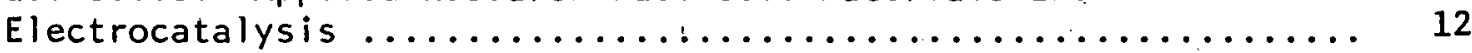

Energy Conservation in Residential Buildings ................ 14

Space Conditioning, Diagnostics, and Controls Technology for

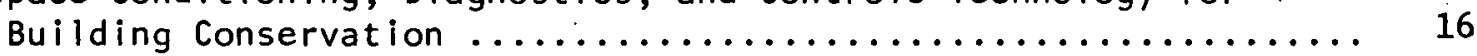

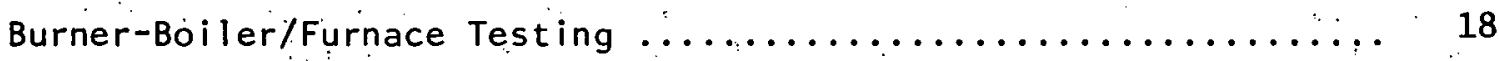

Solar Technology Transfer Program in Northeast U.S. ........... 20

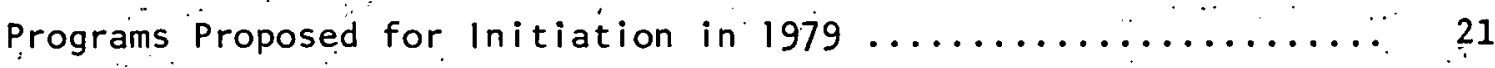

Engineering Division

Technical Support-Solar Heat Pump and Solar Cooling Systems ..... 24

Fossi] Energy Program Development ................... 26

Boiler/Furnace Burner and Industrial Heater Development ....... 27

Secondary Alternate Fuel Combustion Systems .............. 28

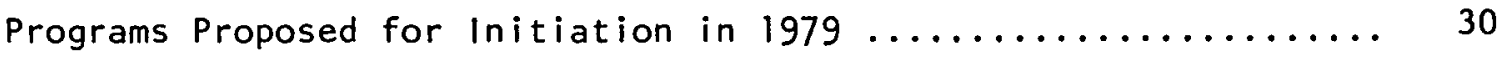

Conservation Program Management Group

Conservation Program Management .................... 32 


\section{INTRODUCTION}

The objective of the Energy Technology Programs in the Department of Energy and Environment is to further the development of advanced energy components and systems. Emphasis is placed on technologies that offer significant improvements in energy conversion systems, the utilization of abundant and renewable sources, and significant improvements in environmental characteristics. Concepts that advance the state-of-the-art well beyond that required by current or contemplated standards are of primary importance.

The Energy Technology Programs involve an integrated approach in collaboration with universities and industry. The work at Brookhaven is directed towards exploratory research and engineering, and supporting research. To provide the basis for eventual commercialization of the technologies under development, work is performed by appropriate industrial groups under contract to Brookhaven.

The Energy Technology Programs are concentrated in the Energy Storage and Conversion Division and the Engineering Division with selected program management activities the responsibility of the Conservation Program Management Group.

The Energy Storage and Conversion Division programs are in two broad areas; electrolysis-based hydrogen energy storage systems and related technologies, and conservation in buildings and community systems.

The hydrogen energy storage activity is directed toward developing storage and transport methods for hydrogen fuel produced from nonfossil sources such as solar, fusion, nuclear, and geothermal. Emphasis is on the production of hydrogen by electrolytic techniques and the development of hydrogen storage facilities for both stationary and mobile applications. A method of storing electrical energy for utility applications that is being investigated is an electrochemically regenerative hydrogen-halogen battery. This system involves electrolysis of hydrochloric (or hydrobromic) acid, storage of the halogen and the hydrogen, and at a later date recombination to generate electric energy. In a related activity fuel cells are being studied because of their potential as high efficiency energy conversion devices for power generation. Current interest is in stationary application with investigation of mobile use planned for 1978. 
The Brookhaven conservation programs in buildings and community systems comprises three residential building technology areas; space conditioning, diagnostics, and energy system controls. Brookhaven responsibilities include the preparation of RDED plans and implementation through in-house work and subcontracts with industry. Brookhaven is currently testing oil-fired space conditioning devices and refit options with plans to include gas-fired units. The objective of this work is to reduce the consumption of oil and gas for space conditioning of residential and commercial buildings.

An allied program is concerned with the building envelope and its integration with the total building system. Areas of interest include: (1) improved energy efficient technologies related to new buildings; (2) retrofit technologies for existing structures; (3) proof of concept evaluation; (4) development of guidelines and criteria to facilitate adoption of energy efficient technologies; and (5) identifying institutional barriers to implementation of energy saving technologies. Again Brookhaven's responsibilities include preparation of RDED plans and implementation through in-house work and subcontracts. A related activity in solar technology transfer is concerned with supporting efforts by state and private groups to accelerate the use of solar energy in the private sector.

The Engineering Division programs include work in solar energy, fossil energy, and combustion technology areas.

The objective of the solar energy technology program is to assist the DOE in the development of solar assisted heat pumps and solar cooling systems, In addition to providing program assistance and technical monitoring, Brookhaven has in-house research activities, initially, the development of residential size simulators for both solar assisted heat pumps and cooling systems.

The objective of the fossil energy development program is to utilize the special resources of Brookhaven to generate processes, and techniques for increasing the utilization of the nation's coal supply. Areas of interest include hot gas desulfurization, catalysis, and particle monitoring and removal in turbine systems.

Brookhaven has direct responsibility for two combustion projects. One is concerned with the improvement of oil and gas fired boilers, furnaces, and industrial process heaters, while the other projects, secondary alternate fuels, deals with wood and waste combustion. Both projects include management and planning activities. 
A Conservation Program Management Group was formed at Brookhaven with planning and management responsibilities in. several program areas of national scope involving RED projects carried out in coordination with industry and universities. The principal responsibilities which were undertaken are: a planning role in defining the overall DOE research program in each area; and an implementation role involving not only research projects at Brookhaven, but also those to be conducted by outside organizations.

Investigators in the energy technology area have ready access to supporting disciplines and techniques residing in other organizational units of the department. These are shown in the following organization chart.

This report presents an overview of, the programs in the energy technology area during 1977. The objective, scope, significant accomplishments in 1977 , principal activities planned for 1978, and publications are presented for each. program. 
DEPARTMENT OF ENERGY AND ENVIRONMENT BROOKHAVEN NATIONAL LABORATORY

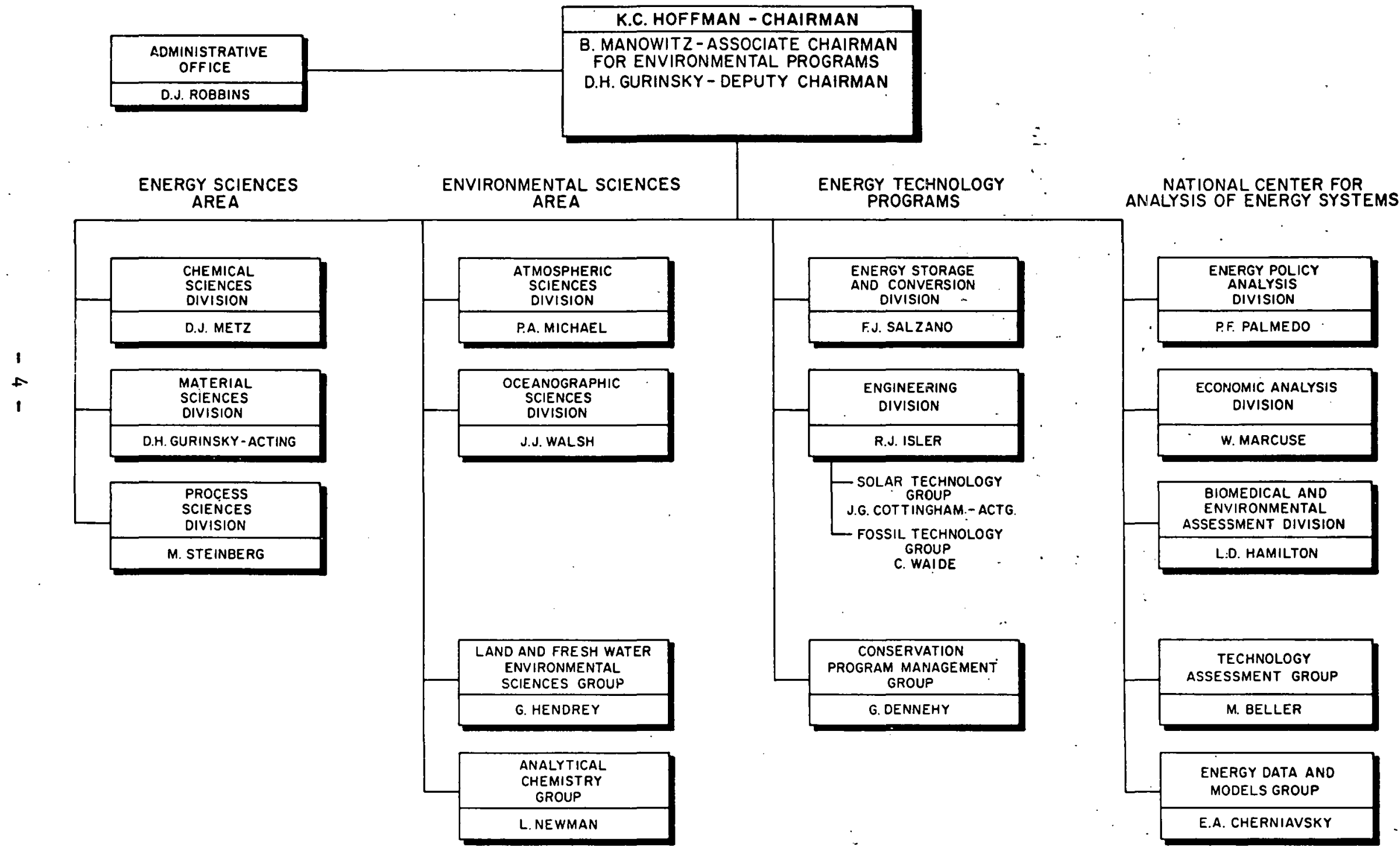


ENERGY STORAGE AND CONVERSION DIVISION

$-5-$ 
FY 1977: $\$ 1,187,000$

Principal Investigator: F. J. Salzano

FY 1978: $\$ 1,700,000$

Sponsor: Chemical and Thermal Branch of Energy Storage and Systems Division (DOE).

\section{Objective:}

The objective of this program is the substitution of hydrogen derived from nonfossil sources as a fuel, storage medium, or energy carrier in appropriate applications. An additional objective is to encourage participation of private industry to assist in the transfer and commercialization of the technology relevant to hydrogen systems.

\section{Scope:}

The project includes the management of contracts issued by BNL, the technical monitoring of contracts issued by $D O E$, the research and development activities performed at BNL, and a liaison function for related hydrogen work done by industry, universities, and other laboratories. The R\&D activities include technology development in areas of electrolytic production, storage subsystems for utility and automotive applications, storage materials work (primarily metal hydrides), near-term end uses, and engineering systems studies to compare technologies and evaluate the economics of potential systems.

Significant Accomplishments in 1977:

1. The design of the first scaled-up version of the General Electric SPE (solid polymer electrolyte) cell stack was completed $\left(2.5 \mathrm{ft} .^{2}\right.$ electrodes).

2. The preliminary assessment of TiCrMn alloys having an available hydrogen content of 2 wt. \% was completed.

3. The study of hydrogen as a supplement to natural gas was completed. Principal Activities Planned for 1978:

1. Complete testing of the first scaled-up version of the General Electric SPE cell stack. 
2. Develop an optimum Mg alloy for automotive applications.

3. Complete testing of first $2 \mathrm{ft}$. diameter by $3 \mathrm{ft}$. long test vessel made of carbon steel.

Publications in 1977:

\section{Journal Articles}

Gottesfeld, S., Srinivasan, S. Electrochemical and Optical Studies of Thick 0xide Layers on Iridium and Their Electrocatalytic Activities for the oxygen Evolution Reaction. To be published in Electroanalytical and Interfacial Electrochemistry. (BNL 22027)

Russell, P. G., Kovac, N., Srinivasan, S., and Steinberg, M. The Electrochemical Reduction of Carbon Dioxide, Formic Acid, and Formaldehyde. To be published in the Journal of the Electrochemical Society, 1977. (BNL 22157)

BNL Reports

Lu, P. W. T., and Srinivasan, S. Nickel Based Alloys as Electrocatalysts for Oxygen Evolution from Alkaline Solutions. January 1977 (BNL 22275)

Salzano, F. J., Editor. Hydrogen Storage and Production In Utility Systems, Semi-Annual Progress Report. July 1, 1975 to December 31, 1975. (BNL 50590).

Russell, P. G., Kovac, N., Srinivasan, S., and Steinberg, M. The Electrochemical Reduction of Carbon Dioxide, Formic Acid, and Formaldehyde. (BNL 22157R)

Lu, P. W. T., and Srinivasan, S. Nickel Based Alloys as Electrocatalysts for 0xygen Evolution from Alkaline Solutions. (BNL 22654)

Srinivasan, S., Olender, H., Miles, M. H., Davidson, C. R., Tseung, A. C. C., and Isaacs, H. S. Electrocatalysis of the Oxygen Electrode Reaction in Acid, Alkaline and Buffered Electrolytes. (BNL 22825)

Rosso, M. J.,. Strickland, G., and Milau, J. S. Pressure Drop--Fluid Flow Correlation for Fixed Beds of Small Irregularly Shaped Particles. (BNL 50589).

Milau, J., Rosso, M. J., and Strickland, G. Some Observations on the Effects of the Volumetric Expansion of Iron-Titanium Hydride on Vessels Built at BNL. (BNL 23130)

Strickland, G. State-of-the-Art Summary of the Technical Problems Involved in the Storage of Hydrogen Via Metal Hydrides (Extended Abstract). (BNL' 23161) 
Lu, P. W. T., and Srinivasan; S. Electrochemical-Ellipsometric Studies of Oxide Films Formed on Nickel During Oxygen Evolution. (BNL 23207)

Johnson, J. R., and Reilly, J. J. The Reaction of Hydrogen with TiCr2 and the Use of Ternary Ti-Cr Transition Metal Alloys for Hydrogen Storage. (Abstract BNL 23258)

Isaacs, H. S., Russe11, P. G., Srinivasan, S., and Tseung, A. C. C. Studies on Glass Composites and Doped Rutile and Interconnection Materials. (BNL 23352)

Lu, P. W. T., and. Srinivasan, S. State of Development in the Area of Water Electrolysis (Near Term). (Abstract BNL 23485)

Lu, P. W. T., and Srinivasan, S. Electrochemical-Ellipsometric Studies of Oxide Film Formed on Nickel During Oxygen Evolution. (BNL 23487)

Johnson, J. R., and Reilly, J. J. The Metal Hydride Development Program at Brookhaven National Laboratory. (BNL 23574)

ERDA Report prepared for the Ad Hoc Committee. An Evaluation of the Use of Hydrogen and a Supplement to Natural Gas. June 1977 (TID-27747)

\section{Oral Presentations}

Lu, P. W. T., Srinivasan, S. Electrochemical-Ellipsometric Studies of Oxide Films formed on Nickel during Oxygen Evolution. 15lst Meeting of the Electrochemical Society, Philadelphia, PA, May 8-13, 1977. (BNL 22120-A)

Salzano, F. J. Hydrogen Technology Development Program at Brookhaven National Laboratory. Proceedings--ERDA Contractor's Review Meeting on November 8 and. 9, 1976, Airlie, VA. (BNL 22158)

Salzano, F. J., and Srinivasan, S. Proceedings of the First International Energy Agency Water Electrolysis Workshop. (BNL 21165).

Isaacs, H. S. The Kinetic Dependence of Iron Catalyzed Graphite Oxidation of 0xygen Potential. Thirteenth Biennial Conference on Carbon, Irvine, CA, July 18-22, 1977. (BNL-NUREG 22736)

Beaufrere, A., Yeo, R. S.; and Srinivasan, S. The Hydrogen-Halogen Energy Storage System for Electric Utility Applications. 12th Intersociety Energy Conversion Engineering Conference, Washington, D.C., August 28 - September 2, 1977. (BNL 22820)

Isaacs, H. S. The Influence of Impurity Distribution and Gas Composition on Graphite Oxidation in Helium. Conference: American Nuclear Society 1977 , 
Winter Meeting, San Francisco, CA, November 27. - December 2, 1977. (BNL-NUREG 22411)

Johnson, J. R., and Reilly, J. J. The Use of Manganese Substituted

Ferrotitanium Alloys for Energy Storage. Alternative Energy Sources Symposium, Miami, Florida, December 5-7, 1977. (Abstract BNL 23145). 


\section{AN ELECTROCHEMICALLY REGENERATIVE HYDROGEN-HALOGEN ENERGY STORAGE SYSTEM}
FY 1977: $\$ 285,000$
Principal Investigators: J. McBreen and S. Srinivasan
FY 1978: $\$ 325,000$
Sponsor: Battery Branch of Energy Storage Systems Division (DOE)

Objective:

The objective of this program is to assist industry in developing and demonstrating, in the near term, a cost-effective electrochemically regenerative hydrogen-halogen energy storage system.

\section{Scope:}

The hydrogen-halogen activity includes work on the electrochemical subsystem, the halogen storage subsystem, materials, cell studies, and economic assessments. The initial effort is directed at the hydrogen-chlorine system.

The program also includes assisting DOE in the technical monitoring of the following Advanced Battery Programs: (1) Zinc-Bromine; (2) Zinc-Chlorine; (3) Redox Systems; and (4) Air Cathodes for Chloralkali Cells. Significant Accomplishments in 1977:

1. The technical feasibility of the $\mathrm{H}_{2} / \mathrm{Cl}_{2}$ electrochemical system has been demonstrated with electric-to-electric efficiencies of $61 \%$ at $300 \mathrm{~A} / \mathrm{ft} .{ }^{2}$. This has been achieved through the use of a flow-through chlorine electrode. 2. A $0.05 \mathrm{ft}^{2}$ cell, complete with auxiliary hardware, has been designed for the definition of system processes.

3. The characterization of the system was begun including a heat and mass balance and a determination of the Nafion membrane resistivities in $\mathrm{HCl}$ concentrations between 5 and $30 \%$ at temperatures between 23 and $85^{\circ} \mathrm{C}$.

4. A preliminary engineering assessment of the $\mathrm{H}_{2} / \mathrm{Cl}_{2}$ system was completed by Bechtel. 


\section{Principal Activities Planned for 1978:}

1. Multicell units consisting of $0.05 \mathrm{ft}^{2}$ cells will be evaluated at both BNL and General Electric.

2. The effect of the chlorine/hydrochloric acid storage subsystem on system performance, cost, and heat balance will be evaluated.

3. The system pressure, temperature; and flow ranges will be defined.

Publications in 1977:

BNL Reports

McBreen, J. Batteries--An Overview of the State-of-the-Art. (BNL 23297).

Oral Presentations

Beaufrere, A., Yeo, R. S., and Srinivasan, S. The Hydrogen-Halogen Energy Storage System for Electric Utility Applications. 12 th Intersociety Energy Conversion Engineering Conference, Washington, D.C., August 28 - September 2, 1977. (Abstract BNL 2208i)

Yeo, R. S., and Srinivasan, S. An Evaluation of the Electrochemically Regenerative Hydrogen-Chlorine Cell for Energy Storage. Electrochemical Society Meeting, Atlanța, Georgia, October 9-14, 1977. (BNL 22776). 


\section{FUEL CELLS: APPLIED RESEARCH FUEL CELL MATERIALS AND ELECTROCATALYSIS}
FY 1977: $\$ 165,000$
Principal Investigator: S. Srinivasan
FY 1978: $\quad \$ 225,000$
Sponsor: Power Systems Division of Fossil Energy (DOE)

Objective:

The fuel cell program at Brookhaven involves research on fuel cell materials and electrocatalysis. Its objectives are (1) to coordinate BNL research with that of other researchers, including industry; (2) to assist industry in the development of a first generation fuel cell system; (3) to establish a research base for the second, third, and future generation fuel cells; and (4) to explore a regenerative fuel cell system as an energy storage device. Scope:

The approach will be to interact with industry, the universities, and other research organizations on basic problem areas; to perform supporting research in problem areas for first, second, and third generation fuel cells; and to work on advanced concepts. Results will be applied in workshops and publications, and in assisting DOE Headquarters in monitoring contracts, reviewing proposals, and planning.

Significant Accomplishments in 1977:

1. Completed development of technique for in situ measurement of electrode surface area.

2. Completed development of technique for regeneration of electrode surfaces.

3. Characterized solid electrolyte in air and hydrogen.

4. Characterized electrode in solid electrolyte fuel cells with noble metals in air and hydrogen.

5. Defined properties of duplex interconnector materials. 
Principal Activities Planned for 1978:

1. Electrocatalytic study and survey of methanol fuel cells.

2. Perform survey and hold workshop on fuel cell electrocatalysis.

3. Determine the electrokinetic effects of electrode structure, composition, and morphology on electrode kinetics in solid electrolyte fuel cells.

4. Determine the influence of electrode and electrolyte structure and composition on cell aging in solid electrolyte fuel cells.

Publications in 1977:

BNL Reports

Isaacs, H., Russell, P., Tseung, A., and Srinivasan, S. Solid.0xide

Fuel Cells: Electrode Kinetics and Interconnection Materials. (BNL 22877).

Hamilton, D., Kerwin, W., McBreen, J., McCormick, B., and Srinivasan, S.

Fuel Cells for Transportation. (BNL 23405)

Oral Presentations

Isaacs, H. S., Russell, P. G. Electrochemical Characteristics of $\mathrm{ZrO}_{2}-\mathrm{Y}_{2} \mathrm{O}_{3}$ Solid Electrolytes for Fuel Cells. 15lst Meeting of the Electrochemical Society, Philadelphia, PA, May 8-13, 1977. (Abstract BNL 22086)

Isaacs, H. S., and 01mer, L. J. An AC Technique for Characterizing.

Solid Oxide Fuel Cells. Workshop on High Temperature Solid Oxide Fuel Cells, Brookhaven National Laboratory, May 5-6, 1977. (Extended Abstract BNL 22793). 
FY 1977: $\$ 200,000$

FY 1978: $\$ 320,000$
Principal Investigators: G. Dennehy and S. C. Carhart (NCAES)

Sponsor: Architectural and Engineering Systems, Branch of the Division of Buildings and Community Systems (DOE)

\section{Objective:}

The objective of the program is to provide program planning and analysis, in-house research, and technical and/or administrative management of RDED conducted by subcontractors.

\section{Scope:}

This program provides support to DOE in the residential buildings area of the Architectural and Engineering Systems Branch RDED effort. The Brookhaven National Laboratory responsibilities include preparation of detailed RDED plans and implementation through in-house work and subcontracts with industry. The responsibility for subcontracts includes technical and/or administrative management, with the extent of control dependent on the particular program element.

The projects will fall in the following areas of the AES program:

(1) RDED of new and improved energy efficient technologies related to new buildings.

(2) RDED of retrofit technologies related to existing buildings.

(3) Proof of concept evaluation and use encouragement of appropriate existing or prototype technologies to maximize their market penetration potential.

(4) Development of guidelines and criteria for building design, construction and operation of buildings to facilitate widespread adoption of energy efficient technologies and practices.

(5) Identifying and overcoming institutional (e.g., financial, legal, and socio-economic) barriers to implementation of energy saving technologies and designs. 
Significant Accomplishments in 1977:

1. A project was developed for research of residential buildings designed for natural thermal storage. The RFP was prepared and proposals were received and evaluated.

2. Program planning study completed. This study, along with the study done by the American Institute of Architects (AIA) Research Corporation, formed the basis for the selection of research projects, to be subcontracted in FY 1978 and FY 1979.

3. The initial development of the Interactive System for Calculating Energy Use was completed.

Principal Activities Planned for 1978:

1. Contractor selection for the Natural Thermal Storage house project.

2. Preparation of user manual for the Interactive System for Calculating Energy Use.

3. Monitoring of the Arkansas House and the installed heat pump system.

4. Applying the Diagnostic Method for Assessing Residential Space Heating Performance to existing houses on Long Island.

Publications in 1977:

NONE 
SPACE CONDITIONING, DIAGNOSTICS, AND CONTROLS

TECHNOLOGY FOR BUILDINGS CONSERVATION

FY 1977: $\$ 370,000$

Principal Investigators: G. Dennehy and . L. M. Woodworth

FY 1978: $\$ 1,100,000$

Sponsor: Consumer Products and Technology Branch of the Division of Buildings and Community Systems (DOE)

Objective:

The objective of this program is to conserve domestic energy supplies by reducing energy consumption in residential and light commercial buildings through improved technology.

Scope:

'This program provides for planning and management of the RDED effort in three areas of the Technology subprogram of Consumer Products and Technology Conservation--Space Conditioning, Building Diagnostics, and Building Systems Controls. The Brookhaven responsibilities include preparation of detailed RDED plans and implementation through in-house work and subcontracts with industry. The extent of responsibilities for specific subcontracts include technical and/or administrative control, depending on the program element, the desire of DOE to maintain management responsibility, and the technical capability of BNL in the specific area.

Sign ificant Accomplishments in 1977:

1. A program plan was completed and specific subcontract projects were identified in each of the three areas of the program--space conditioning, building diagnostic systems, and building systems controls.

2. Six contracts were placed by Brookhaven in the Consumer Products and Technology area.

Principal Activities Planned for 1978:

1. The planning, budgeting, scheduling, and monitoring activity will continue. 
2. The long-range plan will be updated as required by progress on individual contracts and changes in overall objectives.

Publications in 1977:

NONE 
FY 1977: $\$ 385,000$

Principal Investigators: R. J. Hoppe and J. E. Batey

FY 19.78: $\$ 460,000$

Sponsor: Consumer Products and Technology Branch of the Division of Buildings and Community Systems (DOE)

Objective:

The objective of this program is to provide technical data on burnerboiler/furnace performance to support the DOE RDED program in Space Conditioning Technology. The DOE program is directed toward achieving a reduction in the consumption of oil and gas for space heating of residential and commercial buildings.

Scope:

This testing program provides technical information for use in support of the DOE RDED program in Space Conditioning Technology, with the objective of achieving a significant reduction in the consumption of oil and gas for space heating of residential and commercial buildings. The work includes development and refinement of test methods based on enthalpy flow efficiency measurements, and construction and operation of test stands for oil and gas fired heating equipment. The testing falls in three general areas:

(1) Characterization of available commercial equipment.

(2) Evaluation of modifications to systems and operating procedures.

(3) Evaluation of developmental equipment with potential for significantly improved performance on a seasonal basis.

Significant Accomplishments in 1977:

1. One hydronic test stand was operated. The equipment tested included boilers, furnaces, burners, vent dampers, and stack heat reclaimers.

2. One forced warm air test stand was built. Construction of an additional hydronic test stand was initiated. 
Princlpal Activities Planned for 1978:

1. Completion of the second hydronic test stand.

2. Emissions monitoring equipment will be used in conjunction with the efficiency testing apparatus.

Publications in 1977:

BNL Reports

Batey, J., Gazerro, V., Salzano, F. J., and Berlad, A. L. Energy Management in Residential and Small Commercial Buildings. Annual Report 1976, July 1976. (BNL 50576)

Berlad, A. L., Salzano, F. J., and Batey, J. Energy Transport Control in Window Systems. September 15, 1976.' (BNL 50586)

Berlad, A. L. Full Efficiency Zone Heating. June 1977. (BNL 23035) Berlad, A. L., Lin, H. C., Batey, J., Salzano, F. J., Yu, W. S., Hoppe, R. J., and Allen, T. Seasonal Performance and Energy Costs of $0 \mathrm{il}$ or GasFired Boilers and Furnaces. March 1977. (BNL 50647) 
SOLAR TECHNOLOGY TRANSFER PROGRAM IN THE NORTHEAST U.S.

FY 1977: $\quad \$ 120,000$

Principal Investigator: W. L. Graves

FY 1978: $\quad \$ 98,000$

Sponsor: Technology. Transfer, Solar Energy Division (DOE)

\section{Objective:}

The objective of the solar technology transfer program is to assist industry, nonfederal government agencies, and public interest groups in bringing solar technologies into broad use in the near term in the Northeast U.S.

Scope:

The Solar Technology Transfer Program (STTP) deploys heating engineers and architects in field offices covering Federal Regions 1, 11, and Region 111 north of the Potomac River. The field engineers work with professional, trade, and government organizations to promote the use of solar energy in place of nonrenewable resources. Secondary efforts to the same end are made with the mass media, educational, and public interest groups.

Significant Accomplishments in 1977:

The program office was set up at BNL with four field architect/engineers located in Vermont, Connecticut, and New York City.

Principal Activities Planned for 1978:

Funding for the program was discontinued after the first quarter of $F Y$ 1978 resulting in the program terminating December 31, 1977.

Publications in 1977:

NONE 


\section{PROGRAMS PROPOSED FOR INITIATION IN 1979}

1. Performance of High Temperature Solid Electrolyte Systems

2. Morphology of Electrode Materials 
THIS PAGE

\section{WAS INTENTIONALLY LEFT BLANK}


ENGINEERING DIVISION 
FY 1977: $\$ 395,000$

Principal Investigators: J. G. Cottingham and P, C. Auh.

FY 1978: $\$ 480,000$

Spansor: Solar Applications Branch, Division of Conservation and Solar Applications (DOE).

Objective:

The objective of the program is to assist the Solar Application Branch of the Division of Conservation and Solar Applications of the DOE in the development of solar assisted heat pump and solar cooling technologies.

Scope:

Initially, Brookhaven was responsible for one activity dealing with the heat pump area. As the DOE solar program expanded, Brookhaven's responsibilities increased to include the solar cooling area.

The support to DOE consists of performing various technical tasks to aid the Solar Application Branch in the identification and development of cost effective solar assisted heat pump and solar cooling technologies for application in solar heating and cooling schemes. BNL is also developing in-house solar assisted heat pump and solar cooling research activities, which are an integral part of the solar RED program.

Significant Accomplishments in 1977:

1. Solar development laboratory constructed.

2. The solar assisted heat pump simulator and the solar cooling simulator were designed along with a computerized control system.

Principal Activities Planned for 1978:

1. Operation of the solar assisted cooling simulator.

2. Development of the solar assisted heat pump simulator and the computerized control system. 
Publications in 1977:

\section{BNL Reports}

Andrews, J. W., and Wilhelm, W. Low-Cost Site-Assembled Solar Collector Designs for Use with Heat Pumps. May 1977 (BNL 50671)

Auh, P. C. A Survey of Absorption Cooling Technology in Solar Applications. (BNL 50704) 
FY 1977: $\$ 200,000$

Principal Investigator: 'C. H. Waide

FY 1978: $\$ 100,000$

Sponsor: Coal, Liquids and Gases. Division, Energy Technology (DOE)

\section{Objective:}

The objective of this program is to initiate fossil energy projects that utilize the capabilities of the Laboratory in supporting the DOE Fossil Energy program. The program will bring specific fossil energy problems to the attention of BNL staff members having special capabilities and will make the Laboratory's resources more readily available to the DOE-FE staff.

Scope:

Brookhaven will identify problem areas in fossil energy programs and will develop relevant projects utilizing BNL staff and consultants. Initial areas of interest are hot gas desulfurization, particle detection and removal, and catalysis.

Significant Accomplishments in 1977:

1. A program was established to investigate the use of multi-metallic bifunctional catalysts for the conversion of coal derived synthesis gas to methanol.

2. A program was established to investigate the feasibility of utilizing a rotating fluidized bed containing limestone for the removal of sulfur from hot gases.

Principle Activities Planned for 1978:

1. The implementation of a new program in direct sampling of particulate mass in coal-fired post-combustion gas streams.

2. The implementation of a new program to investigate the feasibility of rotating baffles in a cyclone to improve collection efficiency.

Publications in 1977:

NONE 
BOILER/FURNACE BURNER AND INDUSTRIAL PROCESS HEATER IMPROVEMENT

FY 1977: $\$ 100,000$

Principal Investigators; C. H. Waide and C. R. Krishna

FY 1978: $\quad \$ 122,000$

Sponsor: Power Systems Division of Fossil Energy (DOE)

Objective:

The objective of the program is to improve the utilization of energy and resources by modification or retrofit of combustion processes and equipment and to provide means for switching to more available fuels.

Scope:

Brookhaven will manage the project contract activities for the DOE Power Systems Division and engage in experimental, analytical, and tectinical assessment activities in support of the management effort. The management aspects of the project include the definition of research needs, development of a program plan, preparation of requests for proposals or program opportunity notices, review of proposals, preparation of procurement packages, and the monitoring of the resultant contracts.

Significant Accomplishments in 1977:

1. A program plan was establi ished and the elements of a supportung laboratory activity were developed,

2. BNL personnel contributed in the establishment of the IEA Combustion Commit tee.

3. A contract procurement plan was established.

Principal Activities Planned for 1978:

Prepare studies on pulsed combustion, condensation heat recovery, combustion control systems, and scaling factor development.

Publications in 1977:

NONE 
FY 1977: No Funding

FY 1978: $\$ 150,000$
Principal Investigator: J. E. Manuel

Sponsor: Power Systems Division of Fossil Energy (DOE).

Objective:

The primary goal of the Secondary Alternate fuel (SAF) Program is to develop technology for the efficient and environmentally acceptable combustion of industrial, commercial, and residential wastes and biomass residues.

\section{Scope:}

Brookhaven National Laboratory will provide project management support for the DOE Combustion Technology Program in the development of combustion systems for Secondary Alternate Fuels.'

BNL's responsibilities will include assisting the DOE in the preparation of detailed RED plans, preparation and evaluation of RFP's, evaluation of unsolicited proposals, and technical monitoring of subcontracts. These activities will be performed as requested by the DOE-FE staff. BNL will implement the project management role by judicious use of BNL expertise, consultants, and subcontractors.

Significant Accomplishments in 1977:

The project was initiated in October of 1977. The contract and planning activities started by DOE were transferred, for management purposes, to BNL during the remainder of the year and liaison procedures between BNL and DOE were established. A subcontract was initiated to provide technical services to DOE.

Principal Activities Planned for 1978:

The procurements planned for 1978 will be implemented. Systematic procedures for monitoring contract activities and reporting will be established and followed as the contract activity increases. Program plans will be 
prepared to ensure that secondary alternate fuel use is developed as rapidly as possible.

Publications in 1977:

NONE 
1. Direct Sampling of Particulate Mass in Coal-Fired Post-Combustion Gas Streams

2. Feasibility of Rotating Baffles in a Cyclone to Improve Collection Efficiency

3. Kolbel-Engelhardt and Related Syntheses

4. The Highly Dispersed Phase in Catalyst Formation and Catalysis Studies 
CONSERVATION PROGRAM MANAGEMENT GROUP

(9)

$-31-$ 


\section{CONSERVATION PROGRAM MANAGEMENT}

FY 1977: $\$ 230,000 *$

FY 1978: $\$ 354,000 \%$

$*$
Principal Investigator: G. Dennehy

Sponsor: Contributing program areas

"These funds are included in the funding shown for the four program areas.

Objective:

The objective of the conservation program management activity is to carry out planning and management responsibilities. in four program areas:

(1) Hydrogen-halogen energy storage systems.

(2) Electrolysis based hydrogen storage systems.

(3) Energy conservation in residential buildings.

(4) Space conditioning, diagnostics, and controls for buildings conservation.

Scope:

The principal responsibilities that are undertaken by Brookhaven in this activity are:

(1) A planning role in defining the overall DOE research program in each area.

(2) An implementation role involving not only the research projects to be conducted at BNL, but also those to be conducted by outside organizations under contract to the Laboratory.

Significant Accomplishments in 1977:

1. Establishment of the Conservation Program Management Group (CPMG) in April 1977.

2. Placement of 18 subcontracts representing approximately $28 \%$ of the total program funds for the four program areas.

Principal Activities Planned for 1978:

Greatly expanded planning and technical monitoring in all four program areas.

Publications in 1977:

NONE 